\title{
リアルタイム車両運動解析を用いたタイヤーサスペンション 特性評価システムの開発*
}

\author{
椎葉 太-*1, 河内 亮*2, 森田恵介*2
}

\section{Development of an Evaluation System of Tire and Suspension Characteristics with Real-Time Vehicle Dynamic Analysis}

\author{
Taichi SHIIBA*3, Ryo KAWAUCHI and Keisuke MORITA \\ ${ }^{* 3}$ Department of Mechanical Engineering, Meiji University, \\ 1-1-1 Higashi-Mita, Tama-ku, Kawasaki-shi, Kanagawa, 214-8571 Japan
}

\begin{abstract}
A new concept of a tire and suspension evaluation system based on the real-time vehicle dynamics analysis with measured tire force is discussed in this paper. A testing machine was developed by authors following this concept, in which a six degree-of-freedom motion platform was used to realize various contact conditions of the tire. It is well known that the tire characteristics are important factors for the dynamic analysis of an automobile, and the suspension setting has a strong influence to the contact conditions of a tire. Therefore, it is important to evaluate the tire characteristics including the effects of the suspension system. The test results with developed testing machine were compared with the running test results using an actual automobile, and the advantage of the new concept and developed tire-suspension testing machine was discussed.
\end{abstract}

Key Words: Automobile, Meneuverability, Ride Comfort, Vehicle Dynamics, Tire, Suspension System, Motion Platform, Hardware-in-the-Loop Simulation

\section{1. 緒言}

自動車のタイヤは，車両の構成要素において唯一路 面と接触し，力の伝達を行う部分である.このため, 車両運動解析の分野においてタイヤの特性を正確に把 握することは重要である. しかしながら，タイヤはゴ ムの持つ材料特性などから強い非線形性を有しており， その力学特性を把握することは容易ではない(1,2).

一方，タイヤの状態に影響を及ぼす要因として，車 体とタイヤを連結するサスペンション機構が挙げられ る. ホイールの上下ストロークに伴うアライメント変 化，およびスプリングやダンパなどの特性は，タイヤ の接地状態に影響し, 結果として車両の挙動にも影響 を及ぼす(3,4). 従って，車両運動を評価する際には，夕 イヤ単体の特性のみではなく，サスペンションの特性 を含めて評価を行うことが重要である.

車両運動解析の手法として，近年ではマルチボディ ダイナミクスの普及により，サスペンション機構を忠

* 原稿受付 2009 年 11 月 10 日.

*1 正員, 明治大学理工学部 (业 214-8571 川崎市多摩区東三由 1-1-1).

*2 明治大学大学院理工学研究科.

E-mail : shiiba@isc.meiji.ac.jp
実に再現した多自由度モデルを利用して，精度の高い 解析が実現されている. しかしながら，タイヤやラバ 一ブッシュなどの要素は非線形特性を有しており，厳 密なモデル化を行うことは困難である．このため車両 開発のプロセスにおいては，車雨運動解析による評価 に加え，実重走行試験による評価が重視されている. 一方で，実車走行試験では路面状態や走行経路などの 条件を常に同一にすること，およひ任意の走行条件を 実現することが難しいという側面がある.

そこで本研究では，タイヤおよびサスペンションの 特性が車両運動特性に与える影響を様々な条件の下に 実験的に評価するため，6 自由度モーション装置と実 車サスペンション機構を用いたタイヤ - サスペンショ ン特性評価システムの開発を行った。 この評価システ ムでは，試験機から計測されるタイヤ力を利用してリ アルタイムに車両運動解析を実行し，得られた解析結 果を利用してモーション装置を制御することにより， 車両が走行している状況を考慮した上で，様々なタイ ヤの接地状態を再現することを特徴としている．本研 究で開発したタイヤーサスペンション特性評価システ 么を図 1 に示す. 
本論文では，開発したタイヤーサスペンション特性 評価システムの構成とリアルタイム車両運動解析につ いて述べた後，スラローム走行試験を模擬した評価試 験と実車による走行試験を比較することにより，開発 したシステムの妥当性を評価する.

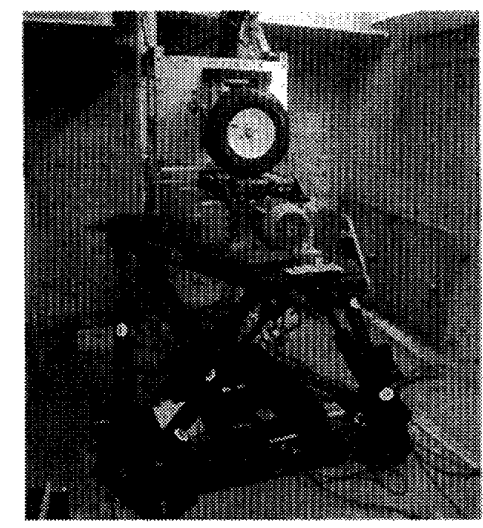

Fig. 1 Tire-süspension testing machine

\section{2. タイヤ - サスペンション特性評価システムの構成}

開発したタイヤーサスペンション特性評価システム は，実車のタイヤおよびサスペンション機構，ローラ コンベア，スチュワートプラットフォーム方式の 6 自 由度モーション装置によって構成されている.

タイヤおよびサスペンション機構の構成を図 2 に示 す. 実車走行試験との比較を行うため, タイヤおよび サスペンション機構は，筆者らの研究室で製作した小 型電気自動車(図 3)の左前輸のものを利用している.こ の小型電気自動車の諸元を表 1 に示寸.この表におい て，車体の質量についてはドライバを含めた值を示し ている.また，ステアリング部のラックピニオン機構 には DC サーボモータが取り付けられており，タイヤ に転舵を与えることが可能である. タイヤに発生する 力は, ナックル部に取り付けられている 6 分力計によ って計測される.

ローラコンベアは AC モータによって駆動されてお り，タイヤを転動させている．製作したローラコンベ アでは, 車速 $40 \mathrm{~km} / \mathrm{h}$ まで模擬することが可能である. なお，タイヤ特性の計測においては, スチールベルト を利用したフラットベルト式タイヤ試験機を利用する ことにより精度が良い計測が実現されることが知られ ているが(6), 本研究では予算的な制約により, 自作し たローラコンベアを利用している.このため実際の車 両の走行状態と比較すると，タイヤ接触面における圧 力分布などに違いが生じ，タイヤ力の特性に相違が生 じることが懸念される.このローラコンベアをフラッ
トベルト式の転動装置に置き換えることによって，よ り精度の高い計測が実現されると考えている.

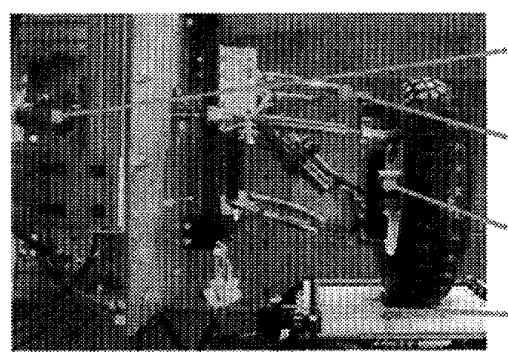

DC servo motor for Rack Gear Double Wishbone Suspension System Tire Force Transducer Roller Conveyer

Fig. 2 Components of suspension system

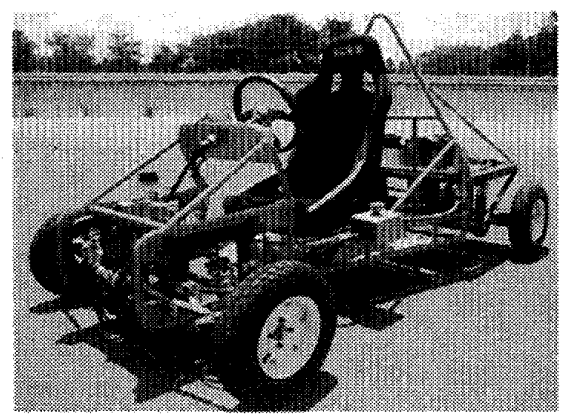

Fig. 3 Experimental vehicle

Table 1 Specifications of experimental vehicle

\begin{tabular}{cc}
\hline Parameter & Value \\
\hline Overall Length & $2205 \mathrm{~mm}$ \\
Wheel Base & $1865 \mathrm{~mm}$ \\
Tread & $1165 \mathrm{~mm}$ \\
Total Weight & $298.2 \mathrm{~kg}$ \\
\hline
\end{tabular}

走行中の車両では，車体のスリップ角変化や姿勢角 変化,および荷重移動などに応じて，タイヤの接地状 態は時々刻々と変化している.この接地状態の変化を 再現するため, 本研究ではスチュワートプラットフォ 一ム方式の 6 自由度モーション装置を利用している.

本研究で開発したシステムの処理の流れを図 4 に示 す.このシステムでは, 計測されるタイヤ力を入力值 として車両運動解析をリアルタイムに実行し, 解析結 果より得られる車体のロール角やピッチ角, ホイール ストロークなどに基づいて 6 自由度モーション装置の 制御を行っている.このため, 開発したシステムはい わゆる HILS (Hardware-in-the-loop Simulation)システム の一種であるといえる. 車両運動解析で用いている車 両モデルの詳細は, 次章にて述べる. タイヤカやタイ ヤの回転速度などの計測, リアルタイム車両運動解析 の実行, および6 自由度モーション装置, タイヤ舵角, ローラコンベアなどの制御は， ISPACE 社製のプロセ ッサボードを用いて行っている. 


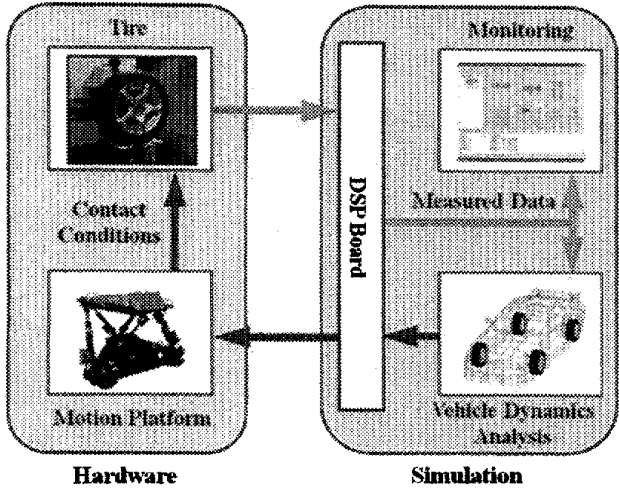

Fig. 4 Overview of HILS system

\section{3. リアルタイム車両運動解析}

$3 \cdot 1$ 車両モデル 車両運動解析に用いる車両モ デルとして，図 5 に示すような車両モデルを用いた. このモデルは，車体の並進運動および回転運動の 6 自 由度に加え, 各車輸の上下運動を考慮した計 10 自由度 モデルとなっている．車両の横運動およびヨー運動の 方程式を式(1)および式(2)に，車体の上下運動，ローリ ング運動，ピッチング運動の方程式をそれぞれ式(3)〜 (5)に，ばね下質量の運動方程式を式(6)に示す．前後方 向の運動については，タイヤ前後力の計測值およびタ イヤ前後力モデルを用いた運動方程式を解くことによ り，車両のダイナミクスとして考慮することも可能で あるが，試験の条件を一定とするため，通常は目標車 速を時系列データとして与えるという形で試験を実施 している. 車両モデルのパラメータは, 前述した小型 電気自動車に基づいて決定している.

$$
\begin{aligned}
& m V(\dot{\beta}+\dot{\psi})=\sum_{i=1}^{4} F_{y}^{(i)} \\
& I_{\psi} \ddot{\psi}=\left(F_{y}^{(1)}+F_{y}^{(2)}\right) l_{f}-\left(F_{y}^{(3)}+F_{y}^{(4)}\right) l_{r}+\sum_{i=1}^{4} M_{z}^{(i)} \\
& m_{s} \ddot{z}_{s}=\sum_{i=1}^{4} F_{s u s}^{(i)} \\
& I_{\phi} \ddot{\phi}=\left(F_{z}^{(1)}-F_{z}^{(2)}\right) \frac{d_{f}}{2}+\left(F_{z}^{(3)}-F_{z}^{(4)}\right) \frac{d_{r}}{2} \\
& \quad+m_{s} V(\dot{\beta}+\dot{\psi}) h+m_{s} g h \sin \phi \\
& I_{\theta} \ddot{\theta}=-\left(F_{z}^{(1)}+F_{z}^{(2)}\right) a+\left(F_{z}^{(3)}+F_{z}^{(4)}\right) b \\
& m_{u}^{(i)} \ddot{z}_{u}^{(i)}=F_{z}^{(i)}-F_{s u s}^{(i)}
\end{aligned}
$$

$m, m_{s}, m_{u}$ ：車両質量, 車体質量(ばね放質量), ばね下質量
$I_{\phi}, I_{\theta}, I_{\psi}:$ ロール・ピッチ・ヨー慣性モーメント

$F_{y}^{(i)}:$ タイヤ横力

$F_{z}^{(i)}:$ タイヤ接地荷重

$F_{s u s}^{(i)}: \quad$ サスペンション上下力

$M_{z}^{(i)}: \quad$ セルフアライニングトルク

$\beta, \psi$ : 車両重心点の横滑り角, $コ$ 一角

$\phi, \theta: \quad$ 車体のロール角,ピッチ角

$l_{f}, l_{r}:$ 前・後輪軸と重心点との距離

$a, b:$ 前・後輪軸とピッチセンタとの距離

$h:$ ロールセンタから重心点までの距離

$d_{f}, d_{r}:$ 前輪・後輪ばねトレッド

$V:$ 車両速度

$g:$ 重力加速度

添字 $i$ : 1 :左前輪, 2 :右前輪, 3 :左後輪, 4: 右後輪

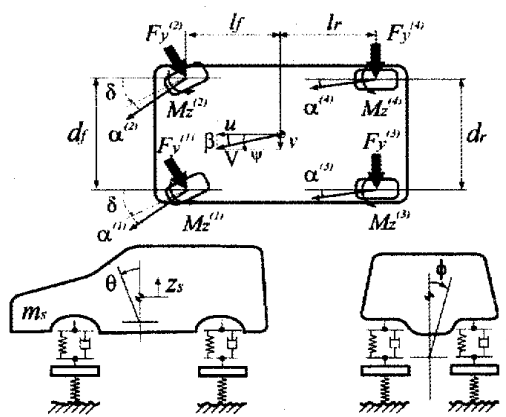

Fig. 5 Vehicle model for real-time calculation

運動方程式に含まれるサスペンション上下力を算出 するにあたっては，以下のような仮定を設けている。

・ スプリングのばね定数は一定とする.

・ダンパの減衰特性は,ダンパ単体試験の結果に基づ いて作成した非線形マップを利用して算出する.

・ スプリングおよびダンパのストローク量とホイー ルの上下ストローク量の比であるレバー比は, 本来 はストロークに応じて変化する值であるが,ここで は一定值としている.

また，運動方程式に含まれるタイヤ横力およびセル フアライニングトルクに関して, 車両モデルの左前輪 については，ナックルに取り付けられた 6 分力計によ って実際に計測された值を利用する。このため，ホイ 一ルの上下ストロークに伴うアライメント変化や荷重 変化など，タイヤに対するサスペンション特性の影響 を考慮することが可能である. 残る 3 輪については, 以下に述べる方法で実験的に同定した線形タイヤモデ ルを利用して，タイヤ力を計算している.

スリップ角およひ接地荷重変動が小さい範囲では, タイヤの横力特性およびセルフアライニングトルクの 特性は，スリップ角および接地荷重変動のそれぞれに 対して比例的に変化することが知られている. そこで, 開発したシステムを利用し， 3 通りの接地荷重条件に おいて，スリップ角に対するタイヤ横力およびセルフ 
アライニングトルクの特性を計測した. 計測結果を図

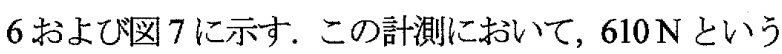
接地荷重の值はドライバ乗車時の車両静止状態におけ る前輪接地荷重であり, さらにその点から $\pm 30 \mathrm{~mm}$ の ホイールストロークが生じたときの接地荷重である $809 \mathrm{~N}$ および $422 \mathrm{~N}$ という值を用いて計測は行われて いる. この計測結果に基づき，タイヤ横力特性を表す 式として，式(7)のようなスリップ角およひ接地荷重に 対する線形近似式を得た。ここで， $F_{y}[\mathrm{~N}]$ はタイヤ横 力, $F_{z}[\mathrm{~N}]$ はタイヤ接地荷重, $\alpha[\mathrm{deg}]$ はタイヤのスリ ップ角である. セルフアライニングトルクについては 值が非常に小さく車両運動特性に与える影響が小さい ことから，今回の計算では無視するものとした.

$$
F_{y}=\left(2.6863 F_{z}+88.296\right) \cdot \alpha
$$

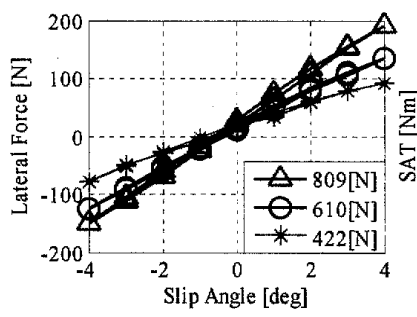

(i) Lateral force

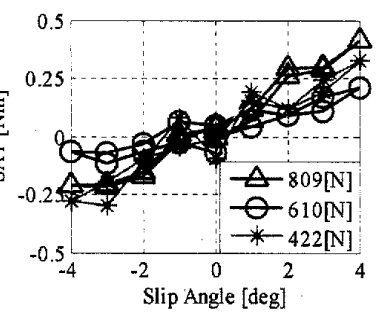

(ii) Self aligning torque
Fig. 6 Tire forces and moments to slip angle

また，タイヤにキャンバ角が生じた際はキャンバス ラストが発生することが知られているが，本論文の夕 イヤモデルではキャンバ角が小さい範囲を取り扱うも のとして，キャンバスラストの影響についても無視す るものとした．以上に述べたように，本論文では，ス リップ角，キャンバ角，接地荷重変動がいずれも小さ いという仮定に基づき，実験結果から同定した線形夕 イヤモデルを利用している. 通常の走行の条件ではこ れらの仮定は成立することが知られているが，いわゆ る限界走行など，非線形領域も含めてタイヤの特性を モデル化する必要がある場合には, Magic Formula モデ ル(5)の導入が有効であると考えている.

$3 \cdot 2$ リアルタイム性の評価 本研究で開発した システムでは，計測されたタイヤ力に基づいて車両運 動解析を行い，その結果を直ちにモーション装置に反 映させる必要がある.このプロセスに遅帯が生じると， 車両の運動に遅れてタイヤの接地状態が変化するため, 実際の車両の走行状況を再現しているものであるとは 言い難い. また, 数值積分のステップ時間が長くなっ てしまうと，解析の安定性が損なわれることが知られ ているため, 安定性を確保するためにも十分早い周期 で車両運動解析を実行する必要がある.
そこで，前節で述べた車両モデルおよびタイヤモデ ルを利用し， dSPACE 社製プロセッサボード DS1104 にて車両運動解析を実行し, 数値積分の 1 ステップに 必要となる計算時間を評価した。このプロセッサボー ドでは，CPU として PowerPC 603e ( $250 \mathrm{MHz})$ が用いら れている. 数值積分法として 4 次の Runge-Kutta 法を 用いたところ，数值積分の 1 ステップに必要となる計 算時間は平均で $0.060 \mathrm{~ms}$ と十分小さい值であること が確認された. なお実際のシステムでは，リアルタイ 公解析の実行周期を $1 \mathrm{~ms}$ として運用を行っている.こ の $1 \mathrm{~ms}$ という害行周期は車両モデルの計算時間に比 べてかなり大きい值であるが，この条件でも安定した 車両運動解析が実現されることが確認されている。

\section{4. モーション装置によるタイヤ接地状態の再現}

本研究で開発したシステムでは, サスペンションが フレームに固定されている. そのため, 実車と同様の タイヤ接地状態を再現するには 6 自由度モーション装 置の制御に配慮する必要がある．本章では，この6 自 由度モーション装置の制御方法を述べる.

$4 \cdot 1$ 車体の姿勢変化 車両が旋回しているとき, あるいは路面凹凸を乗り越える際には，車体のロール およびピッチ運動などの姿勢変化や，バウンシング運 動が発生する.このうちロール運動およびピッチ運動 については, 図7および図 8 に示すように, 車両運動 解析によって算出されたピッチ角やロール角を 6 自由 度モーション装置の指令值として利用することにより， 車体の姿勢変化を再現している. またこのとき, 車両 のロールセンタおよびピッチセンタの位置を考慮して モーション装置を制御している.すなわち，モーショ ン装置は車体と路面の相対的な角度変化を実現するこ とになる.

なお，この方法により相対的な角度をモーション装 置によって実現した場合，害際の車両の運動と比心゙， 車体の姿勢角の分だけ重力の方向が異なることになる. このため, 厳密にはタイヤの接地荷重は実際の車両と は一致していない.しかしながら，この重力の方向の 影響は, 例えば $5 \mathrm{deg}$ という車体姿勢変化としてはか なり大きい值を想定した場合でも， $1-\cos 5^{\circ}=0.38 \%$ 程度である. さらに, タイヤの接地力はサスペンショ ンのスプリングおよびダンパによる反力が主因となっ ており，パーツに作用する重力の影響は小さい，従っ て，この重力方向の違いが与える影響は無視できる程 度と考えられる。

また，車体の上下方向の運動であるバウンシング運 動についても，車雨運動解析の結果得られるタイヤと 
車体間の相詨ストロークに基づいてモーション装置の 上下位置を決定することにより，スプリングおよびダ ンパの動作条件を実際の車両運動と同様のものとして いる.

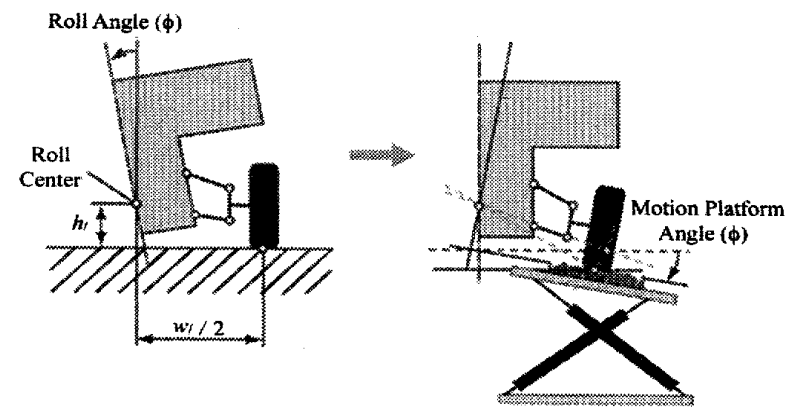

Fig. 7 Emulation of roll angle

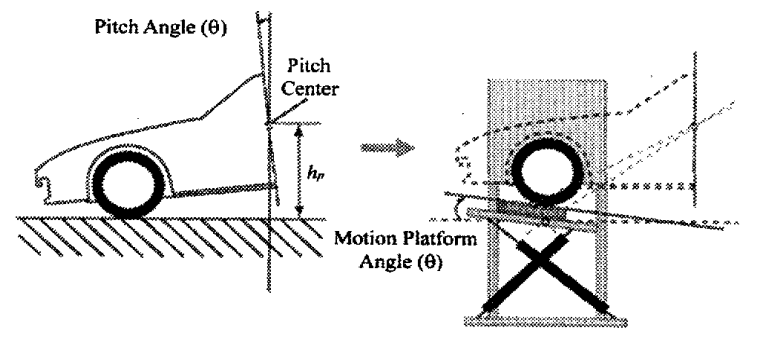

Fig. 8 Emulation of pitch angle

$4 \cdot 2$ 車体スリップ角の考慮旋回中の車両には タイヤにスリップ角が生じる.このタイヤのスリップ 角を再現するためには，ステアリングの操舵角に加え， 車体の横すべりの量を表す車体スリップ角，より厳密 にはタイヤ接地点における車体スリップ角を考慮する 必要がある.

本研究で開発したシステムでは，ラックピニオン機 構に取り付けた DC サ一ボモータを制御することによ りステアリング操舵角を再現し，併せてモーション装 置を利用して車体スリップ角を再現することで，タイ ヤに適切なスリップ角を与えている.
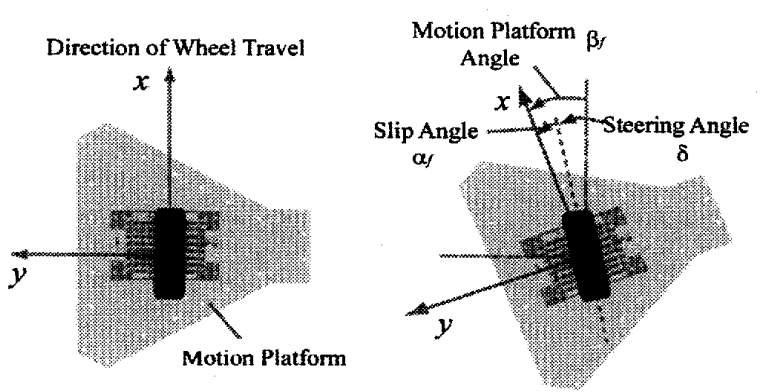

Fig. 9 Emulation of slip angle

\section{5. 車両走行試験との比较評価}

本研究で開発したタイヤ - サスペンション特性評価 システムの妥当性を確認するため，試験車両を利用し
てスラローム走行試験を実施し，開発したシステムに よる試験結果との比較を行なった．試験車両によるス ラローム走行試験では，車速をほぼ一定として正弦波 状の操舵角を与え, 操舵角, 車速, 車体重心点におけ る横加速度，およびヨーレートの計測を行った。開発 したシステムによる試験では，走行試験における平均 車速 $22 \mathrm{~km} / \mathrm{h}$ を一定車速として与えた。 また，走行試験 により計測された舵角(図 10)を DC サーボモー夕の入 カデータとして利用した。

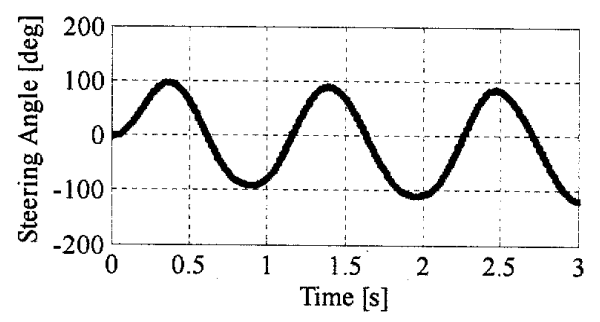

Fig. 10 Steering input for slalom test

試験結果を図 11 に示す. 開発したタイヤ - サスペン ション特性評価システムによって，走行試験と同様に スラローム走行の状況が再現できていることがわかる． なお走行試験の結果には，横加速度およびヨーレート の計測結果に路面の凹凸に起因するノイズが含まれて おり，また車速も完全に一定とはなっていない，走行 試験と開発したシステムによる試験を比較すると，舵 角に対する横加速度やヨーレートの遅れはよく再現で きているものの, 横加速度やヨーレートの振幅に差異 がみられることがわかる。これは，発生しているタイ ヤカに違いが生じているためと考えられる．車両のヨ ーレートゲインや横加速度ゲインなどの特性は，タイ ヤ力が大きく影響することが知られている，しかしな がら開発した試験機では，前述したように予算的な制 約によりタイヤ転動装置としてローラコンベアを用い ているため，タイヤの接地圧分布やすべり現象が実際 の路面に対するものと異なっていると考えられる，路 面の摩擦特性なども含め, タイヤと路面の接触状況を より正確に再現することにより，車両運動についても 再現精度を向上させることができると考えている。

以下に，今回開発したシステムについて，実車によ る走行試験と比較した際の有効性を述べる．まず開発 したシステムでは，走行条件の任意性が高いことが挙 げられる. 開発したシステムでは，車両の重量や重心 位置といったパラメータを車両モデルにおいて考慮し ているため,これらのパラメータは容易に変更するこ とができる. 更に，今回の論文では走行路面を平坦な ものとして取り扱ったが，路面形状を車雨モデルに対 する入力として考慮することにより，路面の凹凸やう 

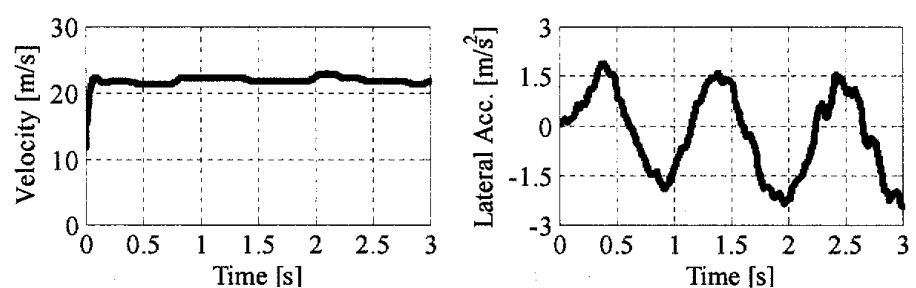

(i) Running Test
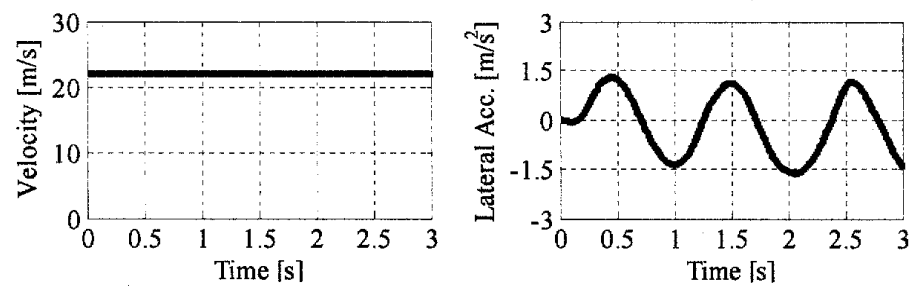

(ii) Developed evaluation system
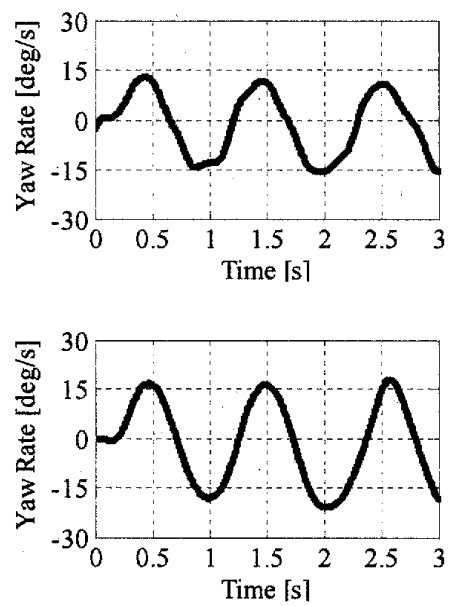

Fig. 11 Slalom running test results

ねりといった点についても多様な条件を作り出すこと が可能である.

また，開発したシステムのメリットとして，同一の 走行条件を提供できることが举げられる．実車による 走行試験では，気象や気温などの条件により，走行す る路面の状態が変化する．また，車速や走行コースな どの走行条件を同一にするためには，熟練したテスト ドライバが必要である.

更に，開発したシステムでは，実車を利用した走行 試験では計測が困難な状態量についても評価が可能で あることが挙げられる．車両を開発する際には，サス ペンションを支持するブッシュの弾性変形によって生 ビる操舵，いわゆるコンプライアンスステアを含めて 車両特性を評価することが重要であるが，このコンプ ライアンスステアの角度は非常に微小であり，走行中 の車両において計測を行うことは困難である。，一方開 発したシステムでは，レーザ変位計を利用して静止系 から精度の高い計測を行うことが可能である(の).また， 実車による走行試験では，車体の横すべり角や姿勢角 を検知するためには高価な計測器が必要であったが， 開発したシステムでは，これらの值は車両運動解析の 結果より得ることができるため, 計測機が不要となっ ている.

以上のように，開発したシステムでは，走行条件の 任意性および同一性，さらに状態量の計測性といった 点にメリットがあると考えられる. 近年ではアクティ ブサスペンションやアクティブステアリングなど様々 な車両運動制御技術が提案されているが，開発したシ ステムは，これらの技術を効率よく評価する圾験環境 として利用できることが期待される.

\section{6. 結 語}

本研究では，タイヤーサスペンション系の特性が車 両運動特性に与える影響を評価するため, 6 自由度モ ーション装置と実車サスペンション機構を用いたタイ ヤ - サスペンション特性評価システムの開発を行った. このシステムでは, 試験機から計測されたタイヤカに 基づきリアルタイムに車両運動解析を行い，解析結果 を利用して 6 自由度モーション装置を制御することに よって, 様々な走行状態を再現することが可能である. 開発したシステムの有効性を評価するため, 実車を利 用したスラローム走行試験を行い，システムにより仮 想的に実現された走行試験の結果と比較した。開発し たシステムにおいて，実車による走行試験と同様にス ラローム走行の状況を再現できることが確認された.

\section{文献}

(1) Dixon, J. C., Tires, Suspension and Handling, Society of Automotive. Engineers, Inc., (1996)

(2) Haken, L., Essers, U. and Wohanka, U., Tire Force and Moment Characteristics Measured on Real Roadways, JSATA, Vol. 26, pp. 495-502, (1993)

(3) Blundell, M. and Harty, D., The Multibody Systems Approach to Vehicle Dynamics, Elsevier Butterworth-Heinemann Ltd., (2004)

(4) Gillespie, T. D., Fundamentals of Vehicle Dynamics, Society of Automotive. Engineers, Inc., (1992)

(5) Pacejka, H. B., Tyre and Vehicle Dynamics, Elsevier Butterworth-Heinemann, (2002)

(6) Shiiba, T., Yamato, K., Kobayashi, K., Okada, T. and Morita, K., Evaluation of Tire and Suspension Characteristics with 6-DOF Motion Platform, Proceedings of the ASME 2007 International Design Engineering Conference, DETC2007-35217, (2007) 